\title{
ENKELE SURINAAMSCHE PRODUCTEN IN NEDERLAND IN 1932
}

\author{
DOOR
}

\section{Ir. W. SPOON}

Tusschen het Landbouwproefstation te Paramaribo en de Afdeeling Handelsmuseum van het Koloniaal Instituut te Amsterdam bestaat reeds sedert jaren een geregelde briefwisseling. $\mathrm{Nu}$ eens wordt uit Paramaribo gevraagd in hoeverre er kans zou bestaan op afzet van een of ander Surinaamsch product in $\mathrm{Ne}$ derland en elders in Europa, dan weder wordt van Amsterdam uit de aandacht gevestigd op een zich voordoende mogelijkheid van levering in de een of andere richting. Wij meenen te dezer plaatse sommige onderwerpen waarover in het afgeloopen jaar van gedachten is gewisseld, te mogen bespreken, omdat er resultaten zijn verkregen, die voor enkele producten van Suriname een ruimere belangstelling hebben doen ontstaan. Wanneer wij daarna die onderwerpen kort aanstippen, moge voorts blijken, dat eenzijdigheid niet bepaald het kenmerk ervan genoemd kan worden. Als product van den kleinen landbouw zal de honig besproken worden, gevolgd door een beschouwing over de sinaasappelen, die zoowel in klein- als in groot-bedrijf worden voortgebracht. Vervolgens enkele boschproducten, eerst het melksap van de bolletrie, daarna een reeks vischvergiften, zooals de nekòe, driekantie, enz.

De laatste jaren zijn af en toe partijtjes ho n i g door Suriname uitgevoerd, de volgende cijfers kunnen daarvan een beeld geven:

UITVOER VAN HONIG, IN LITERS

\begin{tabular}{l|r|c|c|r|c}
\hline \hline Jaar & Totaal & $\begin{array}{c}\text { Naar naburige landen } \\
\text { Curaçao, Aruba, } \\
\text { Br. Guiana }\end{array}$ & $\begin{array}{c}\text { neder- } \\
\text { land }\end{array}$ & $\begin{array}{c}\text { Duitsch- } \\
\text { land }\end{array}$ & $\begin{array}{c}\text { Enge- } \\
\text { land }\end{array}$ \\
\hline 1929 & 1.385 & - & 200 & 1.185 & - \\
1930 & 10.396 & 50 & - & 10.346 & - \\
1931 & 3.435 & 787 & - & 200 & 2.448 \\
1932 & 15.615 & & & &
\end{tabular}


Duitschland en Engeland blijken dus af en toe partijen afgenomen te hebben, Nederland echter na 1929 niet meer. Op een blijvende belangstelling voor de Surinaamsche honig in één der genoemde landen duiden de cijfers echter niet. Om daarvan de oorzaak te vinden en dus de juiste waardeering te leeren kennen, deed het Landbouwproefstation ons in de eerste helft van 1932 een flinke proefzending van de honig toekomen.

In Nederland wordt veel honig verbruikt. Daarmede bedoelen wij niet alleen het gebruik als tafel-artikel, maar vooral het belangrijke industrieele gebruik, d. w. z. in de industrie van koekwerken, biscuits, banketwaren e.d. De omvang van het gebruik blijkt eenigermate, als men ziet, dat naast de eigen productie van gemiddeld 1000 ton, telkenjare nog een kleine 4000 ton ingevoerde honig in ons land verwerkt wordt. Het zijn voornamelijk Cuba, Jamaïca, Haïti, Mexico en Chili, die Nederland en de overige landen van Europa van honig voorzien.

Honig staat in Nederland onder een controle van overheidswege; in het Honigbesluit van de Warenwet zijn de eischen omschreven, waaraan het artikel moet voldoen om voor de consumptie toegelaten te worden. Een der eerste dingen, die ons dus te doen stonden, was in het laboratorium na te gaan, of de ontvangen honig aan de kwaliteits-eischen van het Honigbesluit voldeed. Het bleek alles in orde te zijn, zoodat uit hoofde van de Warenwet tegen het in consumptie brengen van de honig geen bezwaar zou zijn te maken. Maar daarmede waren wij er nog niet, want dat beteekende alleen, dat de scheikundige samenstelling in orde was, terwijl het geen uitsluitsel gaf over voor den consument zoo belangrijke eigenschappen als aroma, smaak, enz. Ter opheldering van laatstgenoemde punten riepen wij de hulp in van enkele fabrikanten van koekwaren, biscuits en dergelijke artikelen. Hun oordeel kwam onveranderlijk daarop neer, dat de Surinaamsche honig te dun vloeibaar was en een te bitteren smaak had, niet zoet genoeg was. In de bakkerij kan slechts honig gebruikt worden, die na bekoeling opstijft; het bleek nu aan de beoordeelaars, dat de Surinaamsche honig onder die omstandigheden te dun bleef. De smaak werd weinig doordringend bevonden met een beslist eenigszins bitteren nasmaak; voor de verwerking in koek moet de honig juist zoet van smaak zijn.

Daarmede was wel duidelijk geworden, waardoor de afzet van de Surinaamsche honig steeds tot enkele partijen beperkt was gebleven, de scheikundige samenstelling zal wel steeds aan de 
eischen voldaan hebben, maar de smaak en de consistentie stonden een blijvend gebruik in den weg.

Dat kwam ook tot uiting in de bepaling van de waarde; fabrikanten konden de Surinaamsche honig slechts op ongeveer de helft van de waarde van honig uit Cuba, Jamaïca, Chili, enz., taxeeren. Er is nog een kleine kans op betere beoordeeling, door n.l. de honig niet in kerosine-blikken, maar in houten vaten te verpakken, de algemeen gebruikelijke exportverpakking voor honig. Het is toch niet geheel en al ondenkbaar, dat de bittere nasmaak van de Surinaamsche honig iets met de zoogenaamde „,blik"'-smaak te maken zou hebben. Als materiaal om vaten uit te vervaardigen zou het soemaroepahout (van Simaruba spec.) wellicht goede diensten kunnen bewijzen.

Op initiatief van het Landbouwproefstation is in 1932 de export van sina sap pelen naar Nederland opnieuw ter hand genomen. Enkele getallen over den uitvoer in het algemeen zijn in het volgende tabelletje bijeengebracht:

UITVOER VAN SINAASAPPELEN, IN DUIZENDTALLEN STUKS

\begin{tabular}{l|r|r|r|r|r|r}
\hline \hline \multirow{2}{*}{ Jaar } & Totaal & \multicolumn{3}{|c|}{ Naar naburige landen } & \multicolumn{2}{c}{ naar Europa } \\
\cline { 3 - 6 } \cline { 5 - 7 } & Curaçao & $\begin{array}{c}\text { Bar- } \\
\text { bados }\end{array}$ & $\begin{array}{c}\text { Br. } \\
\text { Guiana }\end{array}$ & $\begin{array}{c}\text { Neder- } \\
\text { land }\end{array}$ & $\begin{array}{c}\text { Enge- } \\
\text { land }\end{array}$ \\
\hline 1929 & 1.307 & 101 & 82 & 1.016 & 104 & 4 \\
1930 & 629 & 422 & 106 & 41 & 60 & - \\
1931 & 988 & 749 & 169 & - & 70 & - \\
1932 & 507 & & & & &
\end{tabular}

Duidelijk blijkt, dat in de laatste jaren de afzet naar Curaçao en. Barbados is toegenomen; die naar Britsch-Guiana kwam in het midden van 1930 tot stilstand, omdat daar toen een verbod voor de invoer van Surinaamsch fruit en groente is uitgevaardigd, in verband met het voorkomen van de vruchtvlieg in Suriname. In den uitvoer naar Nederland vond geen vooruitgang plaats.

Om de moederlandsche markt thans goed te leeren kennen, werden nieuwe proeven opgezet, waarbij het Landbouwproefstation zich belastte met den inkoop, de sorteering, verpakking en verscheping van het fruit, de Afdeeling Handelsmuseum voor haar rekening nam de aanmaak van wikkelpapieren met een pas- 
send vignet en de afzet van de aan te voeren partijen bij de $\mathrm{Ne}-$ derlandsche fruithandel. Een zeer belangrijk punt was, dat de aanvoer uit Suriname hier valt in de zomermaanden, wanneer de vraag naar saprijk fruit groot is, terwijl de voorziening daarin naar verhouding gering is.

Met tusschenpoozen van drie weken brachten de booten van de Suriname-lijn in de periode Augustus-October vier partijen sinaasappelen aan, in totaal 434 kisten. De verzending in het geventileerde scheepsruim bleek goed te voldoen. De kisten waren van het model en de afmetingen, zooals in Brazilië en Californië voor de vruchten-export in gebruik zijn. De aanmaak geschiedde in Suriname uit soemaroepahout en uit possentriehout (Hura Crepitans Linn.); aan de beide korte einden stonden het woord „Suriname” en het stuktal (d. w. z. het getal, aangevend het aantal in de kist verpakte vruchten, b.v. 126, 176, enz.) er op gedrukt. Feitelijk had op die zijwand een kleurrijk etiket moeten voorkomen, waarvan echter wegens de hooge kosten van aanmaak voorloopig afgezien was. Elke vrucht was in een vierkant wikkelpapiertje verpakt, bedrukt met een vignet, waarvoor wij de teekening ontleenden aan het wapen van Suriname.

De verpakking en de sorteering werden door de Nederlandsche handelaren gunstig beoordeeld. Het meest gewild bleken de kisten met 126 tot 200 vruchten, de zeer groote vruchten, waarvan er slechts 90 à 96 in een kist gaan, konden geen veel hoogeren prijs behalen, omdat daaronder naar verhouding nogal eens droge vruchten voorkwamen. De gele inplaats van oranje kleur deed aanvankelijk de koopers wat terughoudend zijn; toen eenmaal de goede kwaliteit en de groote hoeveelheid sap meer bekend werden, begonnen zij over hun vooroordeelen heen te stappen.

Onbevredigend voor Suriname is het verloop van dit eerste exportseizoen dan ook niet geweest. Het Surinaamsche product is thans in vele kringen geintroduceerd, waardoor dit jaar grootere partijen gemakkelijker hun weg zullen kunnen vinden.

Thans komende tot de boschproducten, kan allereerst vermeld worden de b a lat a-melk, het melksap van de bolletrie, Mimusops globosa GAERTN. F., waarvan ons enkele malen door de Europeesche industrie zendingen gevraagd werden. Het Landbouwproefstation verzorgde dan de inzameling, de conserveering met ammoniak, de verpakking en de opzending naar Amsterdam. Alvorens de melk door te zenden naar de betrokken 
industrie gingen wij hier de samenstelling na. Aangezien het melksap steeds onder toezicht was getapt en verzameld, was de kans op vervalsching met latex van andere boomen vrijwel uitgesloten; de verrichte analyses veroorloofden dan ook een inzicht in de juiste samenstelling van balata-melk, zooals Suriname die kan leveren.

Gerekend mag dan worden, dat met ammoniak geconserveerde melk 21 à $22 \%$ gutta bevat, ongeveer evenveel harsachtige stoffen, rond $3 \%$ eiwitachtige stoffen en de dubbele hoeveelheid minerale verbindingen, de rest ad $46-49 \%$ is water.

Andere boschproducten, waarvoor belangstelling merkbaar was, behoorden alle tot de z.g. vis chvergif t e n, zooals nekòe, driekantie, asitjoena, enz. De aandacht viel er op door de groote vraag naar het nieuwe insecticide rotenon, dat reeds aangetroffen is in verscheidene soorten van het in Z.O. Azië voorkomende geslacht Derris en in soorten van het in Zuid-Amerika thuisbehoorende geslacht Lonchocarpus, die alle zonder uitzondering als sterke vischvergiften bekend staan.

De onderzoekers van het „Bureau of Chemistry and Soils” te Washington hebben de aandacht op rotenon gevestigd, omdat het uiterst giftig is voor tal van insecten, zonder nochtans ook maar in eenigerlei opzicht schadelijk te zijn voor den mensch en voor hoogere dieren. Van de thans als insecticide gebruikte arseen- en koperverbindingen kan het laatste helaas niet gezegd worden. Rotenon is een witte kristallijne verbinding, met smeltpunt $163^{\circ} \mathrm{C}$.

Enkele jaren geleden (1929) is rotenon aangetroffen in den wortel van de in Peru en enkele deelen van Brazilië in het wild voorkomende Lonchocarpus nicou (AUBL.) D.C., daar bekend onder den naam cubé. Zoo dicht bij huis, loonde het zeker de moeite na te gaan of nu ook de in Suriname voorkomende Lonchocarpus-soort, de $\mathrm{n}$ e k ò e, ook wel met den naam stinkhout aangeduid, wellicht rotenon bevatte. Het was wederom het Landbouwproefstation, dat de inzameling en opzending van het materiaal verzorgde, waarna reeds in 1931 het onderzoek ervan plaats vond in het laboratorium van de Afdeeling Handelsmuseum.

Terloops is reeds vermeld, dat rotenon in den wortel van de cubé was aangetroffen. Een feit is toch, dat men, ook bij Derris, rotenon voornamelijk in de wortels aantreft; stam en stengels bevatten er steeds slechts heel weinig van. 
Tot dusverre was men voor de kennis van de vergiftige verbindingen van nekòe aangewezen op het proefschrift van W. M. I. Borst Pauwels (Leiden 1903). Deze onderzoeker zonderde uit den stam als giftig voor visschen af, kristallijn wit nekoeïd en harsachtig lichtgeel gekleurd beta-nekoeïd (smeltpunt $125^{\circ}$ resp. $\pm 82^{\circ}$ C.); rotenon (smeltpunt $163^{\circ}$ ) was er echter niet bij. Ons onderzoek verliep gunstiger, zoowel uit den stam als uit den wortel kon rotenon afgezonderd worden, zij het uit den stam slechts zeer weinig, wat, gezien de reeds bekende waarnemingen, ook verwacht mocht worden. Uit nekòe-wortel kon rond $2 \%$ rotenon verkregen worden. Bij het in 1932 voortgezette onderzoek - met nieuw ontvangen materiaal - bleek de opbrengst niet steeds dezelfde, naast partijen wortel met meer dan $2 \%$, waren er ook met slechts ruim 1\%. Het Landbouwproefstation veronderstelt thans, dat die verschillen verband kunnen houden met de bekende bewering van de bevolking in Suriname, dat er een „witte" en een „zwarte" nekòe zou bestaan, van welke de laatste als zwaarder vischvergif wordt beschouwd. Denkbaar is dan ook, dat de zwarte nekòe meer rotenon dan de witte zou bevatten.

Een opmerking op historisch terrein mag hier niet achterwege worden gelaten. In 1895 heeft een Fransch apotheker, E. GEOFFROY stammateriaal van een in Fransch-Guiana voorkomende Lonchocarpus-soort, vermoedelijk $L$. nicou, onderzocht. Daaruit heeft hij een witte, kristallijne stof met smeltpunt $162^{\circ} \mathrm{C}$. afgezonderd, waaraan hij den naam nicouline gaf, afgeleid van de soortnaam nicou. Die waarneming is in de literatuur op den achtergrond geraakt; toen wij haar weder voor ons namen en de beschrijving die GEOFFROY van nicouline geeft, vergeleken met wat wij zelf bij rotenon waargenomen hebben, bleef geen twijfel meer over omtrent de gelijkheid van beide stoffen; inderdaad moet aangenomen worden, dat reeds in 1895 uit Lonchocarpusmateriaal rotenon is afgezonderd, echter onder den naam nicouline.

Voorts mag nu ook aangenomen worden, dat de in 1903 afgezonderde verbindingen nekoeïd en beta-nekoeïd naar alle waarschijnlijkheid nog geen volkomen zuivere stoffen zijn geweest maar tusschenproducten op den weg naar rotenon.

Voor Suriname kan de nekòe-wortel dus van beteekenis geacht worden wegens het feit, dat er het belangrijke insecticide rotenon in voorkomt. Blijkens de statistiek is tot voor kort slechts weinig ervan uitgevoerd, waarin echter in het afgeloopen jaar (1932) 
een opvallende wending is gekomen, zooals de volgende cijfers mogen aantoonen:

UITVOER VAN NEKOE-WORTEL

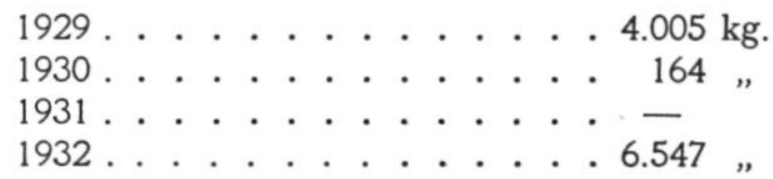

$\mathrm{Er}$ is dus verhoogde belangstelling merkbaar; indien dat verschijnsel het gevolg mocht zijn van de in 1931 verrichte onderzoekingen, zou de arbeid van het Landbouwproefstation en onze instelling reeds tot een voor Suriname gunstig resultaat hebben geleid.

De overige hier onderzochte vischvergiften waren driekantie, asitjoena, koenapaloe, koenami, teteroeman karoembanikoro en oeriri jarithe. Van al deze planten zijn het blad, de stam en de wortels afzonderlijk op de aanwezigheid van rotenon onderzocht. Echter zonder succes, al kon in enkele gevallen wel een kenmerkend bestanddeel aanget oond worden. Zoo bleken stam en wortel van driekantie, Serjania spec. sterk saponinehoudend te zijn, terwijl uit den wortel van asitjoena, Tephrosia toxicaria PERS., een kleine hoeveelheid van een bruine stof afgescheiden werd, waarschijnlijk uit onzuiver tephrosine bestaande. Daarmede waren wij wel betrekkelijk dicht bij rotenon gekomen, tephrosine behoort n.l. met degueline en toxicarol tot de verbindingen, die als regel naast rotenon in den wortel van Derris en Lonchocarpus aangetroffen worden. $\mathrm{Zij}$ zijn alle drie giftig, maar bij lange na niet in de mate van rotenon.

Voorloopig blijft dan ook van de bestudeerde Surinaamsche vischvergiften de nekòe, althans wat den wortel aangaat, degene, die voor de kolonie economische beteekenis kan hebben.

Amsterdam, Januari 1933

Afd. Handelsmuseum v/h Koloniaal Instituut. 